\title{
DEFINIENDO ESTRATEGIAS
} PARA EL ENEMIGO: DE LA ACCIÓN PREVENTIVA A LA OFENSIVA ANTICOMUNISTA. EL ESTADO Y LA SECCIÓN ESPECIAL (1930-1943)

\section{Mercedes F. López Cantera*}

CONICET - UBA / Centro de Estudios

Recibido: 30 de noviembre de 2020

Históricos de los Trabajadores y las Izquierdas

Aceptado: 6 de marzo de 2021

$\bowtie$ mercedes.lopez.cantera@gmail.com

DOI: 10.46553/colec.32.1.2021.p89-128

Resumen: Diversos estudios dedicados al desarrollo del aparato estatal durante los años treinta han hecho foco en aquellos procesos modernizadores de su estructura. En ello se enmarcó la profesionalización de la Policía de la Capital, dentro de la cual la aparición de la Sección Especial de Represión contra el Comunismo fue una pieza clave, que consideramos un punto de quiebre en el empleo de modalidades de disciplinamiento social. Nos proponemos analizar los orígenes y la dinámica desplegada por la Sección Especial entre 1930 y 1943, con el fin de comprender su sentido político más allá de los empeños modernizadores de los gobiernos de la Concordancia, abordando sus recursos y estrategias, las nuevas herramientas implementadas, reconstruyendo de esa manera el origen de una

\footnotetext{
* Doctora en Historia por la Facultad de Filosofía y Letras de la UBA, en donde también se desempeña como docente de la carrera de grado. Es especialista en el desarrollo del anticomunismo de entreguerras en Argentina. Asimismo, es miembro fundador del Centro de Estudios Históricos de los Trabajadores y las Izquierdas (CEHTI) y de la Red de Estudios Interdisciplinarios sobre Derechas (REIDER).

Agradezco los comentarios de los/as evaluadores/as del presente trabajo, como así las críticas de Hernán Camarero, todos ellos insumos necesarios para la profundización de las ideas aquí abordadas.
} 
nueva etapa en la lógica coercitiva en el Estado en torno a la figura del "enemigo comunista".

Palabras clave: represión; anticomunismo; policía; entreguerras; movimiento obrero; comunismo

\begin{abstract}
The aim of this paper is to analize the beginning of the Special Branch for the Repression of Communism, during the modernizing process of the Policía de la Capital in the thirties. This new branch was a inflection point in the use of resources of social discipline. We propose to study the origins and the dynamics displayed by the Special Branch between 1930 and 1943, in order to understand its political meaning beyond the modernizing efforts of the Concordance governments, addressing their resources and strategies, the new tools implemented, thus reconstructing the origin of a new stage in coercive logic of state around the figure of the "communist enemy."
\end{abstract}

Keywords: Repression; Anticommunism; Police; Interwar Period; Labor Movement; Communism

\title{
I. Introducción
}

Dentro del conjunto de las numerosas problemáticas que caracterizaron al ciclo comprendido por el golpe de Estado de septiembre de 1930, la llegada al gobierno de las presidencias de la Concordancia (Agustín P. Justo, 1932-1938; Roberto Ortiz y Ramón Castilo, 1938-1943) y la toma del poder político por la fracción nacionalista del Ejército en 1943, aquellas vinculadas a la conflictividad social-obrera motivaron diversas interpretaciones y respuestas por parte de distintos actores. Aquellos protagonistas identificados con la extrema derecha nacionalista, el mundo católico, el conservadurismo, y el radicalismo antipersonalista (estos dos últimos, a la cabeza de los gobiernos de gran parte del mencionado ciclo), no dudaron en incluir dentro de sus evaluaciones sobre el conflicto social al peligro comunista, diagnóstico que fue compartido con las fuerzas de 
seguridad, en particular la Policía de la Capital. Así, el llamado "terror” rojo se constituyó como el principal argumento en base al cual el Estado argentino de los años treinta desplegó y complejizó su aparato represivo, articulando de esa manera una lógica de disciplinamiento social en clave anticomunista.

Esta última afirmación encierra varios interrogantes sobre los que nos proponemos reflexionar en este artículo. Uno primero es preguntarnos sobre el momento en que el Estado comenzó a apelar al comunismo como una amenaza real o potencial; en segundo lugar, qué conclusiones esa caracterización implicó: qué elementos propios del fenómeno comunista fueron considerados por las fuerzas de seguridad como contrarios a los valores e ideas pilares del orden político, al mismo tiempo de por qué algunos de esos componentes fueron extensivos a otras identidades políticas. Esto último reviste relevancia dado que parte de la bibliografía especializada en la entreguerras argentina concibió al anticomunismo de ese período como una problemática hipertrofiada, negando incluso al comunismo como actor y factor políticos (Rouquie 1978; Zanatta 1996). En nuestro caso, partimos de la comprensión del fenómeno anticomunista en tanto un conjunto de ideas y de prácticas de disiciplinamiento que incidieron en la definición política de diversos protagonistas, como también en el desarrollo de un entramado represivo estatal que colaboró en el control de actividades políticas, cimentando la construcción de la imagen del enemigo (López Cantera 2019). Es esta última dimensión del anticomunismo la que nos interesa explorar en el presente trabajo y la que se relaciona con una tercera pregunta: cuáles fueron los recursos desarrollados por el Estado para contener lo que consideraban una amenaza al orden constituido y cómo fue justificado.

Consideramos que el despliegue de acciones represivas en clave anticomunista permitió elaborar criterios de clasificación en relación a estrategias, banderas y valores políticos, a partir de la observación y control sobre el activismo obrero de los años treinta y cuarenta, donde el papel de la militancia comunista jugó un interés central por parte de las fuerzas de seguridad. ${ }^{1}$ En esa línea, conviene contemplar que la presente investigación

${ }^{1}$ La concepción del anticomunismo como base para la elaboración de criterios de clasificación ha sido desarrollada a partir del caso chileno en Casals Araya (2016). 
busca dar cuenta de un proceso de maduración, de medidas coercitivas pensadas de forma preventiva a otras con una impronta ofensiva. Entendemos que los caracteres preventivo y ofensivo presentan un juego dialéctico; no obstante, al inscribir este estudio en el análisis de los orígenes del anticomunismo, no podemos marginar que concebimos a este último como una expresión contrarrevolucionaria, es decir, ideas y acciones que buscaron o bien negar o bien obturar el avance de un potencial proceso revolucionario y de las transformaciones asociadas al mismo. Esta concepción nos obliga a identificar en qué momento ese discurso y prácticas implicaron un quiebre, un carácter nuevo que significó una dinámica predominantemente ofensiva, a pesar de convivir con modalidades reactivas o preventivas (Mayer 2000, 50-51).

En ese sentido, a lo largo de estos años, en distintas oportunidades, representantes de los gobiernos de la Concordancia justificaron la puesta en práctica de procedimientos preventivos ante la ausencia de herramientas legales para contener a la amenaza comunista, también homologada con "elementos disolventes" o perjudiciales para el orden social y político. A pesar de dicha apelación, no tuvo lugar la promulgación de ninguna normativa a nivel nacional. Ello nos conduce a nuestra primera hipótesis: el desarrollo de ciertas estructuras y prácticas estatales destinadas a ejercer un control sobre actividades políticas que fueron englobadas dentro de esa categoría, habría permitido que el Estado consolide una política represiva anticomunista en los hechos. En segundo lugar, nos remite a evaluar la gestación de una lógica ofensiva por parte del Estado contra aquellas prácticas y banderas políticas que eran calificadas dentro del "peligro rojo". Esta construcción habría sido el resultado del aprendizaje que el aparato estatal experimentó desde la complejización de sus herramientas coercitivas en las décadas de 1900 y 1910, tal como reza la bibliografía citada (Salvatore 2000; Caimari 2001; Barry 2015 y 2019; Franco 2019), hasta la articulación de los distintos componentes de lo que denominamos "entramado represivo" a comienzos de los años treinta. Este entramado se habría configurado a partir de la combinación de normativas legales y contravencionales, acciones preventivas, inteligencia, en el que fue central el accionar llevado a cabo por la Policía de la Capital, en particular la Sección Especial de Represión al Comunismo (SERC), y el respaldo brindado por el Poder Ejecutivo. 
Estos objetivos serán desarrollados en dos partes. Una primera abordará las modalidades represivas de la SERC entre 1932 a 1943, dentro de lo cual comprender sus orígenes será indispensable para ubicar al marco de disciplinamiento del período estudiado en continuidad con aquellos lineamientos que el aparato estatal desplegó en las primeras décadas del siglo. En una segunda instancia de este texto, analizaremos el rol jugado por el poder político estatal, a través de leyes, decretos y edictos contravencionales, a los que sumaremos la posición asumida por el Poder Ejecutivo contemplando los informes del Ministerio del Interior en 1934, 1941 y 1942 presentados al Congreso Nacional.

\section{Origen y desarrollo de la SERC}

Es frecuente encontrar que tanto la bibliografía especializada como la de divulgación han emparentado, e incluso homologado, a la Sección Especial de Represión contra el Comunismo con la Sección de Orden Político, y viceversa. Entre otras cuestiones, las dificultades para reconstruir el recorrido de estas secciones dependientes de la División de Investigaciones de la Policía de la Capital pueden vincularse a aquellas que presenta el acceso a archivos policiales en Argentina (condición agravada por la ausencia de una política de archivo en el país), debiendo los investigadores e investigadoras tener que recurrir a reservorios tangenciales como a la colaboración o solidaridad entre colegas.

En el rastreo de trabajos vinculados a los orígenes de la estructura policial, el punto de partida para la configuración de herramientas de control social y político debe ubicarse en torno al dictado de la Ley de Residencia en 1902 y a la creación de la propia División de Investigaciones, dentro de la cual se organizó en 1906 la Sección de Orden Social (SOS) (Rodríguez 1978; Kalmanowiecki 1997; Barry 2015; Benclowicz 2019). El contexto de gestación de esta última no fue otro que el marco de los conflictos socialesobreros de fines del siglo XIX y comienzos del XX, lo que los actores de la época denominaron "cuestión social". Aunque parte de los estudios dedicados a la primera década de 1900 enfatizaron las tendencias contenedoras y conciliadoras manifestadas y puestas en práctica por representantes de la gestión conservadora (Zimmermann 1995), ello no 
obtura el poder caracterizar a los años que rodearon al Centenario como atravesados por intensas luchas políticas. El escenario de comienzos de siglo evidenció las contradicciones existentes de la "Argentina moderna" y frente a ello el aparato estatal recurrió a perfeccionar los recursos destinados para el control social, donde la represión al anarquismo fue decisiva en la articulación de esas herramientas como en la cooperación policial internacional que colaboró en el desarrollo institucional de la Policía de la Capital (Galeano 2009; Galeano y Albornoz 2016 y 2017).

Aquí deben inscribirse el proceso de profesionalización iniciado por Ramón Falcón hasta su asesinato político en 1909, el consecuente dictado de la Ley de "Defensa Social" en ese mismo año (derogada durante la primera presidencia de Hipólito Yrigoyen) y la creación de la Sección de Orden Público o de Orden Político (SOP) en 1910. La SOP fue un signo de la complejidad que fueron adquiriendo las tareas de disciplinamiento encaradas por la Policía de la Capital. Cabe señalar que esta dependencia definió a sus objetivos dentro del marco político legal: el Partido Socialista (PS), la Unión Cívica Radical (UCR), y la militancia obrera. Distinto fue el caso de la SOS, cuyos intereses se mantuvieron en en la "delincuencia social", lo que incluyó a aquellos sujetos o manifestaciones consideradas como "anomalías sociales" (Kalmanowiecki 1997, 76; 2000). La amplitud de esta categoría permitió englobar tanto al anarquismo y a la mafia, como al "comunismo", expresión empleada sin una definición específica, al menos hasta la irrupción de las transformaciones de las luchas sociales y políticas que marcaron a los años veinte y primeros treinta.

Aquellos elementos que dotaron de un contenido más preciso o concreto a la clasificación de "comunista" por la División de Investigaciones, emergieron de la observación y experiencia represiva que fue desplegada con posterioridad al impacto de la Revolución Rusa y de las consecuencias de la Gran Guerra en la Argentina. Este proceso no puede escindirse de la irrupción de una nueva figura antagónica a los ojos del Estado, clase dominante, conservadores, católicos y otros: el maximalismo. La crisis ideológica de la posguerra a nivel mundial, el desplazamiento de la elite oligárquica del poder del Estado en el plano local, las tensiones sociales producto de los condicionamientos económicos resultantes de la contienda bélica, coincidieron y colaboraron en la aparición de ese fenómeno. En el mismo confluyeron temores gestados en la experiencia represiva contra el 
anarquismo, junto a nuevos elementos en los que la incidencia del ejemplo bolchevique fue central, tal como demostró la masacre de la Semana Trágica y la interpretación y preocupación por este tipo de hechos que registraron fuerzas de seguridad e inteligencia a nivel nacional como internacional (Bilsky 1984; Díaz 2019; Asquini y Koppmann 2020; Lvovich 2020).

Si bien no es objetivo de este trabajo analizar el desplazamiento discursivo del "maximalismo" al "comunismo" realizado por aquellos actores que se comprendieron a sí mismos como "agentes del orden", creemos que la vaguedad del primero abonó la imagen "difusa" endilgada por la bibliografía a las expresiones anticomunistas. Comprendemos que el término maximalismo sintetizó diversas representaciones pero no escapó a ser reflejo de un mismo temor: la disolución del orden tras la toma del poder político. Esto último habría sido introducido por un novel elemento, el ejemplo de la revolución bolchevique (López Cantera 2019, 47-66). En suma, lo nuevo y lo viejo entrelazados en una misma figura que sintetizaba el desorden social, en términos generales, y el peligro revolucionario, en particular. Conjeturamos - y nos proponemos abordar este dilema en futuras investigaciones - que la transición hacia la identificación con el comunismo habría tenido lugar a fines de los años veinte en la Argentina, consolidándose en los primeros años de los treinta en base a la caracterización que desde la represión estatal y la observación de otros actores sobre el fenómeno rojo (católicos y nacionalistas, preferentemente) fue llevada a cabo.

Por otra parte, los años del maximalismo coincidieron con el desarrollo de los gobiernos radicales, la primera experiencia de democracia de masas de la Argentina del siglo XX. Tanto los gobiernos de Hipólito Yrigoyen (1916-1922 y 1928-1930) y de Marcelo T. de Alvear (1922-1928) combinaron políticas de negociación sindical con un ejercicio represivo que no solo marcó continuidades con el del ciclo conservador, sino también con el iniciado tras el golpe de Estado de 1930. En este punto, corresponde hacer mención a la presencia de diversas figuras en la gestión de Alvear, como el caso de Ricardo Ireneo "La Foca" Hermelo, encargado de coordinar las acciones rompehuelgas desde el comité antipersonalista de la UCR que dirigía en el barrio de La Boca (Horowitz 2014, 210-211; Troncoso 1983, 90-92), y que en 1930 sería el primer Jefe de la Policía de la Capital 
designado por José F. Uriburu.2 Hermelo fue desplazado en diciembre del mismo año por Enrique Pilotto, quien nombró a Carlos H. Rodríguez como Jefe de la Guardia del Departamento, una presencia clave en los orígenes de la Sección Especial, hasta julio de 1931 cuando ocupó el cargo de Subprefecto de Seguridad, teniendo bajo su control a la División de Investigaciones y sus respectivas secciones.

Otra referencia que consideramos necesaria es la relativa a la ampliación del presupuesto militar durante esa presidencia, que implicó una mayor inversión en aparatos y recursos bélicos, como la contratación de profesionales extranjeros, en línea con la tradición imperante en el Ejército argentino. El flamante ministro de Guerra, Agustín P. Justo, incorporó a la estructura ministerial a militares rusos exiliados de la URSS que habían pertenecido al ejército zarista durante la guerra revolucionaria. Entre ellos figuraron Alejo o Alexei Vladimirovich von Schwarz, profesor en el Ejército, autor de diversos trabajos sobre estrategia de defensa nacional, y Alexei Woronzoff Veniaminoff. Este último se había desempeñado como oficial de minas del ejército blanco y luego, en Argentina, como ingeniero de construcción en la cartera de Guerra. Según algunos trabajos estuvo relacionado a un "grupo fascista" ruso organizado por "G." Bashkiroff, emigrado en 1927 y fundador del periódico Rus (Publitskaia 2013, 13-14). ${ }^{3}$

Entendemos que en el tiempo comprendido entre el golpe de Estado de 1930 y los comienzos de la "normalidad constitucional" inaugurada con la primera presidencia de la Concordancia, tuvo lugar la gestación de la Sección Especial de Represión al Comunismo. Como hemos referido, algunos/as autores/as han ubicado su creación en torno al año 1931 (Iñigo Carrera 2016; Caimari 2012; Camarero 2007; Kalmanowiecki 1997; Rodríguez Molas 1985; Rodríguez 1978), coincidiendo en caracterizar a la dinámica represiva del año y medio de la dictadura de José F. Uriburu en tanto una "embestida", cuya desmesura colaboró en ampliar el espectro de enemigos del conjunto de los golpistas. Junto al peligro yrigoyenista, el

\footnotetext{
${ }^{2}$ En 1973, Oscar Hermelo, su hijo, por ese entonces juez en lo criminal, llevo adelante una querella contra Troncoso y el periodista Norberto Firpo por "injurias" a raíz de publicar información sobre la actividad represiva de su padre. Por otra parte, el fiscal Oscar Hermelo hijo, nieto de Ricardo, fue imputado en el 2007 por la Megacausa ESMA.

${ }^{3}$ Agradecemos la información y la traducción del ruso a Alexander Dementyev.
} 
gobierno provisional denunció a la amenaza comunista como otro puntal de la batalla política que se proponía dar; aun así, la definición de dicha figura navegó una vez más en aguas poco claras. El disciplinamiento impartido durante esos meses presentó continuidades con la división del trabajo represivo existente en la Policía de la Capital desde comienzos de siglo, y, promediando el ciclo uriburista, fueron incorporados nuevos elementos que incidieron en la posterior conformación de la SERC una vez restaurada la democracia.

De acuerdo a esto último, la SOP tuvo como ejes de su accionar a activistas y miembros del radicalismo yrigoyenista y del PS. El rol jugado por Leopoldo Lugones (h) en la dirección de dicha Sección fue denunciado tras la asunción de Justo como presidente, lo que permitió hacer trascender el uso sistemático de torturas en las dependencias de la División de Investigaciones. ${ }^{4}$ Mientras tanto, la SOS mantuvo sus acciones dirigidas hacia anarquistas y los ahora calificados como comunistas. Estos últimos fueron diferenciados bajo esa categoría en los resúmenes de prontuarios de la lista de detenidos bajo la ley $4144 .^{5} \mathrm{El}$ criterio establecido parece haber residido en la pertenencia de estos sujetos a organizaciones satélites del PC como el Socorro Rojo Internacional o el Comité Obrero y Estudiantil por las Deportaciones (luego conocido como Comité Estudiantil contra el Fascismo), como aquellos encontrados in fragantti en movilizaciones o repartiendo folletos o prensa; o casos puntuales como el de David Grinspan (Prio. 62116 O. S.) docente detenido por ser director de una escuela "...en la que se enseñaba a los niños las teorías soviéticas y el odio de clases."6

4 "Se iniciaron juicios contra los torturadores de la Penitenciaría Nacional", La Vanguardia, año XXXVIII, nro. 86, 02/03/1932, p. 9; "Aquel proceso sobre torturas", en Crisol, año I, nro. 237, 29/10/1932, p. 3. Los testimonios de las víctimas de la SOP durante la dirección de Lugones fueron compilados en el texto Los Torturados, Buenos Aires, Editorial Estampa, 1932. Agradezco a Lila Caimari el haberme facilitado ese material.

5 “Al Sr. Ministro del Interior”, División de Investigaciones de Orden Social, Policía de la Capital, 15 de enero de 1932, folios 84 y 79 respectivamente, Caja 149, Documentos Reservados y Confidenciales, AGN- Intermedio.

6 “Al Sr. Ministro del Interior”, División de Investigaciones de Orden Social, Policía de la Capital, 15 de enero de 1932, Folio 108, Caja 149, Documentos Reservados y Confidenciales, AGN-Intermedio. Entre esos casos catalogados como "peligrosos" se encuentra una mujer, la única que figura en la nómina de los documentos analizados: 
Calificativos como "indeseables", "agitadores peligrosos", fueron aplicados principalmente en los casos de detenidos anarquistas, aunque su empleo no permite concluir si ello incurrió en una variable de diferenciación entre ácratas y rojos.

Debemos contemplar que son pocos los indicios que estos documentos policiales nos sugieren en relación a rastrear los disparadores para la creación de la SERC. Es posible reconocer que la misma fue creada en abril de 1932 no solo por lo señalado en las Memorias de la División de Investigaciones de la Policía de la Capital, sino por la existencia hasta marzo de 1932 de prontuarios de militantes calificados como "comunistas" dentro del legajo de la SOS. Así ilustra el caso del referente sindical Guido Fioravanti, quien desde junio de 1931 se encontraba preso bajo la ley de Residencia, para ser deportado en el vapor Chaco, tras haber sido acusado de "recibir órdenes de "la Central Comunista" y de repartir instrucciones entre militantes de nacionalidad italiana. En marzo de 1932, en el contexto del retorno a la "normalidad constitucional", el presidente Justo ordenó la repatriación de los detenidos en el Chaco, lo que le permitió a Fioravantti y otros recuperar su libertad y reanudar su activismo gremial. ${ }^{7}$ Los prontuarios de todos los afectados se encontraban bajo poder y clasificación de Orden Social. Varios años después, en el contexto de la huelgas encabezadas por los gremios de la construcción en 1937, Fioravantti fue

Encarnación Represas (pro. 58623 O. S.) participante de una banda acusada de cometer "actos de terrorismo".

${ }^{7}$ El resto de los detenidos que estaban confinados en el Chaco y fueron repatriados: Carlos Barrero, Francisco Vallony, Vainfro Pini, Teodoro Lukaszuck, León Nastasbyuski, Ignacio Kiznis, Vicente Mejieskias, Vladimiro Kiscink, Elías Nesternk, Simon Saskel, David Grimberg, Jacobo Mysiak, Isaac Bobron, Luis Urban, Moisés Rafael Szymkieweiz, Aaron Pinchusowiez, José Janis, Augusto Gustavo Lenche, Juan Trnka, Juan Grollo, Benito Sak, Wolf Gitter, Moisés Ber Szwicer, Gustavo Klibingaity, José Strate, Pedro Fabretti, Teófilo Gutierrez, Vicente Longo Triyana, José Zurru, Pascual Alaggia, Pedro Pencak, Pablo Igaszewicz y Guido Fioravanti. División de Investigaciones, SOS, folio 106, y Agustín P. Justo, Decreto 15 de marzo de 1932, folios 247 y 248, Caja 149, Reservados Confidenciales, AGN Intermedio. El prontuario de su detención durante el uriburismo figura en "Al Sr. Ministro del Interior", División de Investigaciones de Orden Social, Policía de la Capital, 15 de enero de 1932, Folio 106, Caja 149, Documentos Reservados y Confidenciales, AGN-Intermedio. 
nuevamente detenido y finalmente deportado a la Italia fascista, aunque en este caso su legajo y antecedentes ya pertenecían a la SERC. ${ }^{8}$

Esto último acompaña la hipótesis de la filiación entre la SOS y la SERC aunque no permite iluminar sobre las razones de la creación de esta última. Y la manera en que es posible echar luz sobre esta cuestión radica en las motivaciones políticas de su creación. En la evaluación tanto del conjunto de hechos como del contexto que atravesaron los años de la transición entre el uriburismo y la llegada al gobierno de la Concordancia, podemos contemplar dos factores que creemos condicionantes del desprendimiento administrativo de la SOS que dio lugar a la Sección Especial. El primero se relaciona a la hipótesis del peligro comunista durante el gobierno provisional y la manera en que éste adquirió un cariz real, concreto, en los meses en que transcurrió la represión. En esa línea debe inscribirse un hito dentro de la dinámica represiva del uriburismo: el allanamiento en agosto de 1931 a la casa comercial Iuyamtorg o Amtorg del Sur. El día 18 de ese mes, la Policía de la Capital había registrado las oficinas de la compañía soviética, lo que dio origen a un informe de la Inspección General de Justicia que fue remitido al Ministro de Interior de Uriburu, ${ }^{9}$ Octavio Pico. En el mismo se dio cuenta de distintas evidencias (como afiches, volantes, folletos, en los que se representaba la colectivización del agro, la defensa militar de la URSS, la ejecución de las burguesías dominantes del extranjero que atentan contra el comunismo ruso y la convocatoria a todos los obreros del mundo a colaborar con la consolidación del socialismo) que acreditaron, según la lectura del gobierno, que esa firma realizaba tareas diplomáticas en representación del gobierno soviético sin conocimiento del gobierno argentino. ${ }^{10} \mathrm{~A}$ su vez, en el documento se señalaba que en noviembre de 1930 la policía había dado cuenta a la fiscalía federal del desarrollo de "actividades comunistas" en la empresa, con motivo de denuncias realizadas por la llamada "Liga Monárquica Rusa", de la que participan miembros de la comunidad de "rusos blancos". Finalmente, la conclusión de la

8 División de Investigaciones, SOS, 21 de septiembre de 1937, folios 1 a 22, Caja 149, AGN Intermedio, Reservados confidenciales.

9 Inspector Dr. Eduardo Guerrico, Inspección General de Justicia, 18 de agosto de 1931, en Crisol, año I, nro. 197, 14/09/1932, pp. 1 y 2.

10 Ídem. 
investigación ratificaba que la Iuyamtorg constituía un enclave soviético dedicado a tareas de propaganda, por lo que dos días más tarde, el 20 de agosto, se emitió un decreto que disolvió la personería jurídica de dicha sociedad anónima, suspendiendo así las relaciones comerciales con la URSS. ${ }^{11}$

La obtención de estos materiales, todos ellos en idioma ruso, habría promovido la organización al interior de la SOS de una oficina "secreta" creada por el Subprefecto Carlos H. Rodríguez, y compuesta por 19 empleados que funcionaban como "traductores", 16 de los cuales habían sido reclutados por Alejo Woronzoff, el ingeniero que quedó a cargo de la coordinación de este espacio. ${ }^{12}$ Mientras algunos autores sostienen que esta oficina constituyó el comienzo de la propia SERC, otras autoras señalan que la misma habría sido "reabierta" con la llegada de Justo al gobierno, ya adoptando el nombre de Sección Especial (Kalmanowiecki 1997; Caimari 2012). Los materiales secuestrados, objeto de esta oficina, fueron aquellas piezas obtenidas por la "censura postal", el chequeo de la correspondencia clasificada por la Dirección de Correos y la correspondiente a encomiendas internacionales de la Aduana. No obstante, creemos que el disparador de este espacio habría estado directamente vinculado con el gran afluente de recursos provenientes del asalto a la Amtorg del Sur. Por otra parte, si bien es probable que la Sección Especial haya incorporado elementos de la de Orden Político (Barry 2019), la nueva dependencia se mantuvo en la misma línea que la de Orden Social.

Es aquí que debemos incorporar al segundo factor: el contexto impuesto por el retorno a la "normalidad constitucional". Las necesidades del nuevo gobierno, dentro de las cuales la resolución de la crisis económica fue la prioridad, implicaron la tarea de diferenciarse del ciclo uriburista, lo que condujo a desplegar variadas herramientas legales para dar marco

\footnotetext{
${ }^{11}$ El informe de la Jefatura de Policía del gobierno provisional al Ministro Pico fue reproducido por Crisol en 1932 (ver "La Iuyamtorg de cuerpo entero ante la opinión pública”, en Crisol, año I, nro. 197, 14/09/1932, pp. 1 y 2). Sobre acusaciones de fraude comercial a la URSS ver: "Cómo realizan su propaganda los soviets", en La Nación, año LXIII, nro. 21857, 4/7/1932, p. 3; "No cabe derogar el decreto acerca de la Iuyamtorg”, en La Nación, año LXIII, nro. 21858, 5/7/1932, p. 1.

12 Esta relación coincide con las afirmaciones presentes en Kalmanowiecki (1997) y Caimari (2012).
} 
institucional a las acciones coercitivas que el gobierno no debía descuidar, tales como las que detallaremos en el siguiente apartado. La apertura democrática luego de febrero de 1932, en combinación con las repercusiones de la crisis internacional, condujo a la reactivación de la vida política. Entre 1932 y 1934 el ciclo de huelgas se reanudó: en 1932 se registraron poco más de 100, entre las que se incluyeron las protagonizadas por la rama del calzado (emprendidas por sindicatos dirigidos por socialistas y anarquistas), las de los trabajadores frigoríficos (que incluyó la creación de la Federación Obrera de la Industria de la Carne por dirigentes comunistas), las de telefónicos, y las del petróleo (Matsushita [1983] 2014, 147 y ss; Ceruso 2015, 87 y ss). Estas últimas, organizadas por la Unión General de Obreros Petroleros en Comodoro Rivadavia (Chubut), concluyeron tras una importante represión impartida por la policía, la Marina y el Ejército, que guiada bajo la hipótesis de la "infiltración comunista" ${ }^{13}$ terminó por deportar alrededor de 1000 trabajadores bajo la Ley de Residencia (Camarero 2007, 181-182).

Fue en este marco en que la División de Investigaciones de la Policía de la Capital inauguró la nueva sección en abril bajo la dirección del comisario Federico Donadío, hasta febrero de 1933 cuando fue reemplazado por el comisario Joaquín Cusell, centro de las denuncias que dieron a conocer la actuación de la nueva dependencia. Según su primer director, esta dependencia había sido creada con el objetivo de “...estudiar el desenvolvimiento del comunismo y poner valla a su propaganda tendenciosa y disolvente.". La justificación y el rol de Donadío se correspondieron con las transformaciones encaradas por el Jefe de la Policía, Luis J. García (ex presidente de la Logia General San Martín en la década de 1920 y figura clave en la interacción policía-Ejército durante el ministerio de Justo en esos años) y el Jefe de la División de Investigaciones, Miguel Viancarlos. Aumento presupuestario, renovación tecnológica, reordenamiento administrativo y archivístico, fueron algunos aspectos del citado "proceso de modernización" policial en los primeros años de la llamada "restauración conservadora".

13 "El conflicto de los obreros petrolíferos", en El Chubut, año X, nro. 2123, p. 5; "Ni la bomba ni el sable", en El Chubut, año X, nro. 2118, 24/04/1932, p. 6. 
La SERC se habría organizado, de acuerdo a las Memorias de Investigación, en base a dos fases. Una primera, administrativa, donde se ubicaron intérpretes de materiales extranjeros, caracterizados como pertenecientes a "grupos considerados "idiomáticos", formados por personas de distintas nacionalidades, especialmente de los países balcánicos". ${ }^{14}$ La abundancia de este tipo de materiales podría emparentarse con la citada "oficina secreta"; aun así es de destacar que esta última habría dejado de funcionar en diciembre de 1931 con la renuncia del Subprefecto Rodríguez, quedado cerrada así su oficina de Sánchez de Bustamante al 2100 (dirección considerada la primer sede de la SERC). La nueva dependencia se instaló en 1932 en los “altos" de la Comisaría 28, en Vélez Sarsfield 160, y luego fue trasladada a Bolívar 666, Comisaría $2^{\circ}$, para finalmente ubicarse en la Comisaría $8^{\circ}$ de Urquiza 566. De esa manera, no habría tenido lugar ninguna "reapertura", sino la erección de una nueva organización que incorporó distintas y nuevas tareas, mientras que las de archivística y traducción continuaron pero solamente conformando un aspecto de la misma.

En efecto, la segunda fase de la creación de la Sección Especial consistió en el despliegue de las acciones de vigilancia y actuación "en las calles". La dinámica que esta asumió implicó su combinación con diversas herramientas de tipo coercitivas que analizaremos a continuación, al tiempo que respondió a una lógica de tipo preventiva relacionada con la hipótesis del "vacío legal" analizaremos en el apartado siguiente.

Primeramente, debemos entender que fue la puesta en práctica de procedimientos lo que le permitió a la Policía de la Capital ir perfeccionando estrategias de vigilancia, inteligencia y, por lo tanto, de control, ejercidas sobre diversos sujetos cuyas acciones e ideas enarboladas eran asociadas al peligro comunista. En suma, la represión desplegada con eje en la SERC nos permite comprender no sólo un proceso de aprendizaje estatal sobre estrategias de disciplinamiento social sino además la manera en que el Estado terminó por configurar esta idea de enemigo homologado al comunismo. Así, resultan decisivas las medidas englobadas dentro de las "tareas de vigilancia" como un primer punto de este análisis. Por empezar,

14 “Al Señor Jefe de la División de Investigaciones”, en Sección Especial, Memoria de Investigaciones. Policía de la Capital Federal, año $1932,1^{\circ}$ de enero de 1933 , p. 77. 
el fin del Estado de Sitio en febrero de 1932 marcó la necesidad de tornar más rígido el control sobre la actividad pública, expresado en el decreto sobre reuniones públicas elaborado por el Ministro del Interior Leopoldo Melo y el Jefe de Policía Luis J. García el 16 de marzo, por el que todo acto o manifestación en la vía pública necesitaba de autorización policial. ${ }^{15} \mathrm{El}$ cumplimiento de esta medida fue acompañada por el incremento de la presencia policial en diversos espacios, lo que fue registrado en informes elaborados por la SOS y por la SERC dedicados a estas actividades públicas como a otras llevadas a cabo en locales gremiales.

La vigilancia impartida sobre el activismo de trabajadores desocupados en los campamentos de Puerto Nuevo y en la organización de las conmemoraciones por el $1^{\circ}$ de mayo en 1932 y en 1933 constituye un primer ejemplo que grafica esa última preocupación; el control sobre la prensa obrera o comunista, el segundo. En relación al primer caso, el despliegue de la observancia en torno al Día Internacional de los/as trabajadores/as en 1933 tuvo lugar en diversos parques de la ciudad de Buenos Aires (tales como Plaza Flores, el Parque de los Patricios, la Plaza Rodríguez Peña en Recoleta, la del 1ero. De Mayo en Balvanera, y las centrales, Británica, Once, Congreso y Constitución), e incluso se dio informe sobre procedimientos similares en Paraná, Concordia, La Rioja, Posadas, Neuquén, Río IV, San Luis, La Plata, Tucumán, Río Gallegos, San Juan, Bahía Blanca (incluyendo Carmen de Patagones, Guaminí, Coronel Suárez, Coronel Pringles y Coronel Dorrego), Salta, Corrientes, Jujuy, Resistencia, Catamarca, Córdoba (como Río II, Las Varillas, Cruz del Eje y Alta Gracia), Santiago del Estero, Santa Rosa, Rawson, Rosario, Mercedes, Pergamino,

\footnotetext{
15 "La lectura de las nuevas normas produce un efecto favorable, pues en ellas se revela el propósito de mantener la tradición liberal, cuya exclusión habría sido inconciliable con las instituciones y la orientación del actual gobierno." En "Una reglamentación democrática", en La Nación, año LXIII, nro. 21760, 18/03/1932, p. 4. Esto generó un amplio debate sobre la regulación del espacio público analizado por Marianne González Aleman (2011). Entre 1932 y 1935, el gobierno de Justo declaró dos Estado de Sitio que se prolongaron más allá de los 30 días establecidos por la Constitución Nacional: el primero entre diciembre de 1932 a mayo de 1933; el segundo, entre diciembre de 1933 y julio de 1934 (Caimari 2012, 227).
} 
Mendoza y Santa Fe. ${ }^{16}$ Este accionar dispuesto a nivel federal da cuenta de la coordinación de las distintas dependencias de la División de Investigaciones, como las SOS y SOP existentes en las policías provinciales.

La nueva sección daba cuenta de esta manera de la realización "en perfecto orden" de los actos y reuniones en cuestión, sin dejar de señalar la pertenencia política de quienes participaban en los mismos. Esto se reiteró en otros eventos de carácter sindical como lo relativo a Puerto Nuevo y gremios en los que el PC tenía presencia militante. ${ }^{17}$ En ese sentido también se inscribió el control sobre la propaganda: la detención de activistas que vendían periódicos obreros o repartían folletos/volantes, como el acoso a publicaciones como Roiter Stern, Bandera Roja, Mundo Obrero y otras no necesariamente vinculadas a la militancia comunista, fueron otros casos relevantes en los procedimientos de la Sección entre 1933 y 1934 (López Cantera 2014b y 2015b).

Los memorandums de la SERC permiten analizar la manera en que la Policía de la Capital se hizo de la información y el conocimiento necesarios para reconstruir la vida política de los sujetos y actores (partidos, sindicatos) observados. Esto implicaba no solo el registro de nombres, sino el destacar algunos ejes temáticos de las reuniones que eran asociados, de acuerdo a las Memorias y otros materiales documentales, al accionar y pensamiento revolucionarios. Entre otras preocupaciones, destacaron el antifascismo y el antimilitarismo, como la convocatoria a huelga general (problemática también registrada por la SOS desde sus inicios). La preocupación que estas reivindicaciones y estrategias de lucha despertaban en las fuerzas de

${ }^{16}$ Memorandum SERC, 3 de junio de 1933 y 6 de junio de 1933, Doc. 115 y 116, Caja 48, Archivo Agustín P. Justo, AGN; y Al Exmo. Presidente de la Nación Argentina, General Agustín P. Justo, Telégrafo de la Nación, 1ro. de mayo de 1933, Doc. 96, folios 249-258, Caja 45, Archivo Agustín P. Justo, AGN.

${ }^{17}$ Memorandum SERC, 16 de mayo de 1933, Doc. 102, Caja 45, Archivo Agustín P. Justo, AGN; Memorandum SERC, Traducción sobre programa teatral en el Salón Vowarts, Rincón 1141 del sábado 25 de noviembre 1933, Doc. 56, Caja 48, Archivo Agustín P. Justo, AGN; Memorandum de la SERC. Festival Comunista, 26 de noviembre de 1933, Doc. 170, Caja 48, Archivo Agustín P. Justo, AGN; Memorandum SERC, 16 de Junio de 1932, Doc. 45, Caja 45, Archivo Agustín P. Justo, AGN. Sobre el activismo de los trabajadores desocupados, ver Iñigo Carrera $(2016,135-145)$ y Benclowicz (2016). 
seguridad, puede comprenderse en tanto una impugnación de las mismas. En ese sentido, es posible observar una operación de calificación y de clasificación, que revelaba la impugnación de valores y tácticas políticas por parte del brazo represivo interno del Estado, lo que en contrapartida implicó la validación de otros elementos constitutivos de la lucha obrera de esos años.

Por otra parte, el interés policial por las líneas políticas desplegadas por el PC, promovió el análisis de las mismas en paralelo a la reconstrucción de las redes establecidas entre organismos y entidades relacionadas con la URSS o con los propios partidos comunistas a nivel mundial. Hasta 1935, año de la adopción de la estrategia de Frente Popular, el comunismo internacional se rigió bajo la línea de clase contra clase, marcada por la intransigencia política hacia otras corrientes de izquierdas, que comprendió, entre otras características, el impulso a "huelgas revolucionarias" (Lobato 2001, 217-224; Camarero 2007, 178-191). Esta estrategia fue representada en las Memorias de la sección y en sus memorandums con el nombre de "Frente Único", en referencia a la formación de entidades como el Comité de Unidad Sindical Clasista (CUSC) - caracterizado como "Comité Sindical de Frente Único" - y otras como la Federación Obrera de la Industria de la Carne o el Sindicato de Obreros de la Industria Metalúrgica (SOIM), protagonistas de importantes luchas durante esos años. El plan de "emulación revolucionaria" impulsado por el propio CUSC tras el levantamiento del Estado de Sitio en 1932, que fue denominado como una acción de "gimnasia revolucionaria" (término empleado por la policía desde comienzos de siglo), junto a la observación sobre la formación de "grupos rojos" o de oposición (otra propuesta del Tercer Período) dentro de sindicatos, fueron señalados por las autoridades policiales como indicios de la expansión comunista y de la lógica destructiva que la caracterizaba. La promoción de conflictos y rupturas al interior de las estructuras gremiales, que significó parte de la estrategia de inserción del PC, ratificaba la esencia "perversa" con la que la policía y otros protagonistas, como el mundo católico, definieron al comunismo en los años treinta.

Si bien no tuvo lugar la concreción del Frente Popular en términos de formación de un frente electoral que nucleara fuerzas antifascistas, desde el liberalismo a las diversas izquierdas, la policía la señaló como una estrategia de mayor peligrosidad al tratarse de un enfoque político en busca de alianzas 
amplias y con pretensión electoral. La primera mención al respecto en las fuentes policiales fue en relación a la conmemoración del $1^{\circ}$ de Mayo en la Ciudad de Buenos Aires de 1936. ${ }^{18}$ Las Memorias y la Revista de Policía y Criminalística coincidieron en que la proyección de dicha táctica podía potenciar la capacidad de infiltración, hasta ese momento observada en el campo sindical, ahora en partidos políticos democráticos. ${ }^{19} \mathrm{El}$ alarma por el desarrollo del frentepopulismo se encontraba respaldado por las repercusiones de la huelga general de enero de 1936, encabezada por el conflicto de la construcción, cuya violencia y enfrentamientos hicieron recordar a la Semana Trágica. ${ }^{20}$ De la misma manera, la fuerza de seguridad no descuidó apelar a los ejemplos de Francia y España en relación a la llegada al gobierno de coaliciones bajo los términos de la nueva línea soviética, como el caso del Frente Popular español o la gestión de León Blum, ambas gestiones representadas como ineficientes y promotoras del caos social (Vigreux 2016, 109-142). En suma, factores internos y externos se entrelazaban para dar cuerpo a este enemigo rojo, confluyendo en él los ejemplos de la Europa atravesada por el ascenso de los fascismos, la nueva

18 "A S. E. Ministro del Interior, del Jefe de Policía Gral. Div. (R.A.) J. E. Vacarezza", en Memoria correspondiente al año 1936, 1ero. de marzo de 1937, pp. 21.

${ }^{19}$ Signorelli, Vicente, "Los Frentes Populares de Europa obedecen a maniobras del Partido Comunista", Revista de Policía y Criminalística de Buenos Aires, tomo I, nro. 6, abril-mayo-junio de 1936, pp. 65, 66 y 84; “A S. E. Ministro del Interior, del Jefe de Policía Gral. Div. (R.A.) J. E. Vacarezza”, en Memoria correspondiente al año 1936, lero. de marzo de 1937, pp. 19-22.

${ }^{20}$ Signorelli, Vicente, "Iniciación del comunismo en Argentina", en Revista de Policía y Criminalística de Buenos Aires, tomo I, nros. 4-5, enero-marzo de 1936, pp. 38-41; "Los sucesos del 7 de enero último", en ibidem, pp. 77- 78. Los nombres de los policías muertos durante la represión con los trabajadores fueron Manuel Rivas, Felipe Velotto y Oscar Gigliani. Sobre el Frente Popular: Signorelli, Vicente, "Los frentes populares de Europa obedecen a maniobras del Partido Comunista", en Revista de Policía y Criminalística de Buenos Aires, tomo I, nro. 6, abrilmayo- junio de 1936, pp. 65-66, sigue en tomo II, nro. 7, julio-agosto-septiembre 1936, p. 84; "A S. E. el señor Ministro del Interior. Del Jefe de Policía, General de División (R. A.) J. E. Vacarezza”, en Memoria Correspondiente al año 1936, Policía de la Capital Federal, $1^{\circ}$ de marzo de 1937. Ver también un análisis similar al caso argentino pero enfocado en el Uruguay: "El comunismo en Uruguay. La memoria de la Jefatura de Policía de Montevideo", en Revista de Policía y Criminalística de Buenos Aires, tomo II, nro. 7, julio-agostoseptiembre 1936, pp. 37-44. 
estrategia de acercamiento y alianzas que reproducía el PC argentino en el ámbito local, y la impugnación a modalidades de protesta del movimiento obrero, tales como la huelga general, la prolongación de conflictos y el empleo de la violencia. Este último componente, más bien un diagnóstico, debe entenderse como resultado de la observación y control profundizados por la Policía de la Capital desde principios de la década, en el que maduraron aquellos balances realizados ante la conflictividad de las primeras décadas del siglo. Así, es posible observar que, para la segunda mitad de la década de 1930, los objetivos de los procedimientos de la SERC presentaban patrones en común.

Dentro del conjunto de valores y modalidades del activismo político que fueron clasificados como "comunistas" y ubicados al margen de la ley, el antifascista se había constituido como una problemática para los intereses de la policía desde comienzos de la década. Los sucesos de la Guerra Civil española (1936-1939), que profundizaron acciones en ese sentido, destacando entre otras las campañas de solidaridad impulsadas por organismos cercanos al PC local (Campione 2018; Piemonte 2015 y 2013), influyeron en la modificación de ciertas regulaciones sobre el espacio público y en el reconocimiento de asociaciones que, como veremos en el próximo apartado, aportaron en la configuración del entramado represivo. Entre 1938 y 1942, el Ministerio del Interior junto a la Policía de la Capital elaboraron una serie de decretos con el fin de estrechar el control sobre actividades públicas y las organizaciones que las llevaran a cabo. La primer medida en ese sentido fue el decreto sobre asociaciones del 15 de mayo de 1939 del Poder Ejecutivo, por el que se prohibió el uso o tenencia de distintivos ajenos a los del Estado argentino, o todo acto relativo a asuntos políticos o de solidaridad con países extranjeros. ${ }^{21}$ Desde el año 1938, el Jefe de Policía, Andrés Sabalain, y el ministro Diógenes Taboada, habían expresado su preocupación por el desarrollo de actos y manifestaciones

\footnotetext{
${ }^{21}$ Poder Ejecutivo, Decreto reglamentario de asociaciones, 15 de mayo de 1939. Ello fue disparado a raíz del llamado "escándalo de la Patagonia" cuando se dio a conocer la denuncia de un supuesto plan de invasión nazi en esa región (Friedman 2010, 91-92; Newton 1995, 240-258).
} 
locales relacionadas a conflictos europeos. ${ }^{22} \mathrm{Si}$ bien el gobierno de Ortiz propuso el citado decreto como consecuencia del activismo filonazi y los choques que este generaba contra la militancia antifascista, el alcance del mismo afectó el desarrollo de aquellas acciones de ayuda o con la II $^{\circ}$ República, los refugiados y refugiadas de la contienda española, eventos que eran señalados en el intercambio epistolar entre Sabalain y Taboada como motivados por "la infiltración de ideas avanzadas" y el objetivo de conquistas adeptos.

La represión contra la movilización antifascista se ve corroborada con el incremento de acciones represivas entre 1940 a 1943 que tuvieron como blanco a entidades y actos de esta índole. El marco legal que acompañó este despliegue se compuso de disposiciones elaboradas en octubre de 1940 y en julio de 1941, que restringieron el acceso a autorizaciones, transitando desde la exclusión de reuniones que fueran contrarias a las "relaciones amistosas" que la Nación mantuviera con otros países, a limitar las autorizaciones solo para actos patrios y partidos políticos con personería, debiendo las organizaciones sindicales tener que realizar sus reuniones en locales cerrados. ${ }^{23}$ Ambas medidas incluían en sus incisos y artículos referencias a la prohibición de reuniones que atentaran a cuestiones como "el orden interno" o "la paz social", al mismo tiempo que otorgaban a la Policía de la Capital la atribución de regular sobre el derecho de reunión.

Esto último, junto a las denuncias que llegaron a la Cámara de Diputados por diversos hechos represivos en el marco de la aplicación de los decretos, sumado al debate sobre la regulación del Estado de Sitio en 1942 a raíz del declarado por Castillo el 16 de diciembre de 1941, condujeron a dos pedidos de interpelación del entonces Ministro del Interior, Miguel Culaciati (López Cantera 2020). El disparador fue el allanamiento del local del Sindicato Único de Obreros de la Construcción (SUOC) y la detención de sus principales referentes, parte de ellos afiliados al PC, entre el 5 y el 8 de

\footnotetext{
${ }^{22}$ A S. E. el señor Ministro del Interior. Del Jefe de Policía, General de Brigada (S. R.) Andrés Sabalain, $1^{\circ}$ de junio de 1938, en Memoria Correspondiente al año 1938, Policía de la Capital Federal, pp. 55-57.

23 "Reuniones públicas. Disposición 857", 25 de julio de 1941, en Disposiciones de Policía, Ministerio del Interior, Policía de la Capital, 434-439.
} 
marzo de $1941 .^{24}$ Esta situación fue discutida en el propio recinto de la Cámara de Diputados que propuso la primera interpelación a Culaciati quien no se presentó -, para exponer sobre los sucesos recientes, dentro de lo cual se incluyó indagar acerca del rol desempeñado por la SERC entre 1940 a $1942 .^{25}$

Los debates en Diputados, junto a un informe y a la interpelación a Culaciati que finalmente tuvo lugar en septiembre de 1942, demostraron que la actuación policial de esos años tuvo entre sus objetivos de control a los actos públicos llevados a cabo por organizaciones sindicales y entidades vinculadas al antifascismo (Bisso 2005: 175-176). Los fundamentos que construyeron la defensa oficial de estos procedimientos, coincidieron en señalar al comunismo como el promotor de estas acciones que, en consecuencia, debían ser consideradas ilegales o delitos. ${ }^{26}$ En el despliegue de estos allanamientos y detenciones, la actuación de la SERC fue protagonista. En paralelo, estos informes dieron a conocer que esa misma dependencia nuevamente actuó en coordinación con la SOS en distintas zonas del país, particularmente en los territorios nacionales. La represión contra entidades como el Comité Pro Ayuda al Pueblo Español y la Junta Territorial de Defensa de la Producción y de la Tierra, como a agricultores en el Territorio Nacional de Chaco, las detenciones bajo la acusación de "agitación comunista" en Misiones, y las persecuciones en La Pampa (Gómez y Salvarredi 2018) dejaron en evidencia el alcance federal de estas

24 "La situación política volverá a ser considerada en el Congreso", en La Prensa, año LXXII, nro. 25931, 09/03/1941, p. 12.

${ }^{25}$ Moción del diputado Manubens Calvet para considerar sobre tablas los proyectos subscriptos por el mismo señor diputado como por otros, y por el señor diputado González, solicitando informes al Poder Ejecutivo por la detención de dirigentes obreros, políticos y estudiantes, en $79^{\circ}$ reunión $23^{\circ}$ Sesión Extraordinaria, 7 de marzo de 1941, HCDN, pp. 487-499. Ver también "La comisión especial del senado se reunirá esta tarde nuevamente. La sesión de mañana en la cámara de Diputados”, en La Prensa, año LXXII, nro. 25933, 11/03/1941, p. 12.

${ }^{26}$ Se considera la interpelación al señor ministro del Interior, relacionada con el Estado de Sitio, en $11^{\circ}$ Reunión $9^{\circ}$ Sesión Ordinaria, HCDN, 24 de junio de 1942, pp 172-173. 
estrategias represivas por medio de las dependencias de la División de Investigaciones de la Policía de la Capital. ${ }^{27}$

El total de las prácticas represivas llevadas a cabo por la SERC nos conduce a reconstruir algunos aspectos de la manera en que el Estado desplegó estrategias de disciplinamiento político en los años treinta y primeros cuarenta. Observar las acciones policiales sin incluir el respaldo político de las mismas y el empleo de otras herramientas, como normas y edictos, sería insuficiente para poder inferir motivaciones políticas detrás de esa represión, lo que incluye a analizar la lógica anticomunista que guió al Estado en estos años. Es por ello que en el siguiente apartado buscaremos completar este retrato, en diálogo permanente con el pasaje de la modalidad preventiva a la ofensiva que hemos planteado en nuestra introducción.

\section{De la acción preventiva a la ofensiva anticomunista. Los otros componentes del entramado represivo}

La apelación al peligro comunista por parte del Estado con anterioridad a la creación de la SERC se manifestó de maneras difusas, contribuyendo a la mencionada hipótesis sobre el desarrollo de un anticomunismo vago, que se sumó a las flexibles caracterizaciones del maximalismo. Ahora bien, creemos que es posible demostrar que el Estado realizó una diferenciación durante los años treinta entre el problema que representaba para sí el comunismo respecto a otros fenómenos como el anarquismo y llamado maximalismo; de la misma manera, entendemos que entre los años veinte y el gobierno provisional es factible señalar algunos pocos ejemplos que demuestran la gestación o la toma de conciencia de esa discriminación.

En referencia a esto último, podemos identificar en esta instancia de investigación, al menos dos antecedentes sobre el rechazo estatal hacia expresiones asociadas al peligro revolucionario que años más tarde sería

${ }^{27}$ Ministerio de Guerra, A S. E. el Sr. Ministro del Interior Doctor Miguel Culaciati. Secreto, 16 de septiembre de 1942, en Caja 6, documento 306, en AGN Intermedio Reservados Confidenciales. Ministerio del Interior, Gobernación de Misiones. Detención y remisión a la Capital Federal del sujeto Marcos Kanner, 1942, Caja 1, documento 147, en AGN Intermedio - Reservados Confidenciales. Respecto a la trayectoria de Marcos Kanner, ver Martínez Chas (2009). 
catalogado como comunista. El primero de ellos se ubica en el contexto del impacto de la revolución: nos referimos al desafuero del senador Enrique del Valle Iberlucea y la anulación de su carta de ciudadanía en 1921. El político y legislador afiliado al PS había tomado posición en favor del proceso bolchevique luego de 1918, siendo el más destacado referente de la tendencia "tercerista" existente al interior de ese partido. A comienzos de 1921, en el $\mathrm{IV}^{\circ}$ Congreso Extraordinario del PS, esta fracción perdió en su intento por incorporar al socialismo argentino en la III $^{\circ}$ Internacional, siendo expulsados en consecuencia (Pittaluga 2015, 61-63; Camarero 2017, 190-192). A raíz de las posiciones adoptadas a favor de las transformaciones de la Rusia revolucionaria, Del Valle Iberlucea fue procesado por la Justicia Federal, impugnándose su carta de ciudadanía (era nativo de España) lo que llevó a que en junio del mismo año se tratara su desafuero. Años más tarde, en 1934, Ángel Rosenblat perdió también su ciudadanía en la ratificación realizada por la Corte Suprema (éste había sido procesado en octubre de 1930) por presentar "...la condición de afiliado y propagandista comunista, contraria a los propósitos constitucionales de la ciudadanía argentina...". ${ }^{28}$

El segundo antecedente que nos interesa mencionar tuvo lugar durante la celebración de los convenios comerciales con la agencia Iuyamtorg durante el segundo gobierno de Yrigoyen. En ese marco, la Junta Electoral rechazó oficializar las boletas del PC por considerarlo como "agraviante para la soberanía nacional”. El juez Miguel Jantus, responsable de varios de los futuros procesamientos impulsados por la SERC, integró la Junta que manifestó su rechazo, respaldándose en las interpretaciones que la prensa antiyrigoyenista y reaccionaria había desplegado en relación a la asociación entre dicho gobierno con la penetración comunista. ${ }^{29}$

Ya en los comienzos de la "normalidad constitucional", el interés del gobierno de Justo por restaurar un marco normativo que acompañara el control necesario para encauzar al "orden" sin necesidad de recurrir a las modalidades de la dictadura de Uriburu, permite comprender la lógica

${ }^{28}$ Corte Suprema de Justicia de la Nación, “Anulación de Carta de Ciudadanía, 10 de agosto de 1934”, en Jurisprudencia Criminal, Policía de la Capital-División Policial, tomo VI, 1934, pp. 175-201.

29 "Revista de la prensa. La supresión de los comunistas", en La Nueva República, año I, nro. 43, 01/12/1928, p. 3. 
preventiva dominante hasta ese momento en las herramientas de disciplinamiento, y observar cómo tenuemente comenzaron a delinearse recursos de tipo ofensivo. Un primer ejemplo lo conforman los intentos de reforma del Código Penal presentados a fines del año 1932, durante los primeros meses de la actuación de la SERC. El Ministro de Justicia Manuel Iriondo (radical antipersonalista y miembro de la Liga Patriótica) y el presidente Justo elaboraron dichas modificaciones que, entre otras, introducían la pena de dos a cuatro años de prisión a todo aquél que por procedimientos ilícitos o de violencia pretendiera alterar el orden constitucional. Si bien la reforma quedó trunca al declararse el Estado de Sitio en el mes de diciembre como consecuencia del complot radical del Coronel Atilio Cattaneo, no deben descuidarse algunas afirmaciones en el mensaje que acompañaba al proyecto, por las que el Poder Ejecutivo aclaraba no buscar la proscripción de ideologías o expresiones políticas, sino aquellos procedimientos que emplearan "...la violencia o medio ilísitos (sic) como recursos para lograr alteraciones del régimen político-social establecido o de las instituciones." ${ }^{30}$

Dentro del conjunto de limitaciones que la División de Investigaciones expresó padecer desde comienzos del gobierno de la Concordancia (principalmente materiales y presupuestarias), la "carencia de recursos legales" fue explicada como un obstáculo que en particular afectaba a la nueva Sección. Este diagnóstico fue reforzado a partir de la experiencia adquirida por la nueva dependencia, que implicó un mayor conocimiento del blanco represivo: "Las libertades concedidas por nuestras leyes hacen que la propaganda bolchevique, esa prédica que conspira contra los principios fundamentales de la sociedad, no pueda ser eficazmente reprimida.". ${ }^{31}$ Ante esa situación, la División y la propia SERC destacaron la importancia de herramientas legales como la Ley 4144 y el problema que significaba la derogación de otras disposiciones como la Ley de Defensa Social (7029), subrayando el apoyo normativo brindado por los edictos

\footnotetext{
${ }^{30}$ Poder Ejecutivo, Reformas al Código Penal vigente. Mensaje y Proyecto de Ley del Poder Ejecutivo, Honorable Cámara del Senado de la Nación, $58^{\circ}$ Reunión, $4^{\circ}$ Sesión Extraordinaria, 13 de diciembre de 1932.

31 “Al Señor Jefe de la División de Investigaciones", en Sección Especial, Memoria de Investigaciones. Policía de la Capital Federal. Año 1935, 1ero. de enero de 1936, p. 244.
} 
contravencionales, que como ha indicado la bibliografía, le permitieron a la Policía avanzar en varias esferas de la vida cotidiana, configurando un "nuevo orden judicial" (Caimari 2012, 95-100). ${ }^{32}$ Corresponde señalar la complementariedad que esas herramientas encontraron en la aplicación de los artículos 209 y 244 del Código Penal, "instigación a cometer delitos" y "portación de armas" respectivamente, las dos normativas más empleadas en las acusaciones contra militantes acusados de "actividades comunistas". Esta articulación contó además con otros recursos, como la constante comunicación entre la Policía con instancias como la Dirección de Correos y Telégrafos a la hora de informar sobre materiales sospechosos, o la aplicación de la Ley 750 de Telégrafos Nacionales de 1875 (Caimari 2012, 95-100), por la que ese servicio podía dar conocimiento a las autoridades policiales sobre información privada que incitase a atentar contra el orden social-político, permitiendo la confiscación de ese material en calidad de prueba judicial. ${ }^{33}$

La reconstrucción de este entramado compuesto por las acciones preventivas de la SERC, leyes como la de Residencia, la aplicación de los artículos del Código Penal, las medidas relativas al servicio de correos, y el empleo de edictos - todo ello acompañado por el Poder Judicial desde los Tribunales Contravencionales y Federales -, ha sido posible a partir del análisis de hechos denunciados por organismos como el Socorro Rojo Internacional (SRI), vinculado al PC, la prensa militante y los informes de la SERC y de las Memorias de Investigaciones. Por ejemplo, el empleo de la Ley 750 fue posible de ser observado en el procesamiento a las publicaciones del PC, Bandera Roja y Mundo Obrero, en 1934, que involucró tareas de vigilancia y la acusación a los involucrados de “asociación ilícita" (Camarero 2007, 191-193; López Cantera 2015b). Asimismo, la información brindada por la Dirección de Correos fue central en los allanamientos en la localidad de Zárate y en ciudad de Buenos Aires que, en mayo de 1933, permitieron dar con participantes del Congreso Antiguerrero convocado en Montevideo en esa fecha. La detención de

\footnotetext{
32 “Al Señor Jefe de la Policía de la Capital”, en Memoria de Investigaciones. Policía de la Capital Federal. Año 1932, 1ero. de enero de 1933, p. 7.

${ }^{33}$ La fecha del fallo es del 26 de octubre de 1932, firmado por el fiscal Dr. Emilio R. Tasada. En Revista Militar, año XXXIII, nro. 387, abril de 1933, p. 143.
} 
militantes se vio acompañada del secuestro de materiales de propaganda que brindaron de nuevos recursos a la Sección. 34

En la exploración de documentos sobre la represión anticomunista en esos años, ha sido central el material brindado por el llamado "informe Melo" de 1934. Resultado de las denuncias en la Cámara de Diputados por torturas y detenciones en el marco del Estado de Sitio de diciembre de 1933 a junio de 1934, en agosto de ese año el Ministro del Interior, Leopoldo Melo, presentó un documento en el que se explicaba las razones de la creación de la SERC y se detallaban los casos de detención por diversos delitos o contravenciones que fueron explicados como parte de las referidas "actividades comunistas" (López Cantera 2014). A partir de este material, el Poder Ejecutivo justificó el accionar preventivo de la Sección como un paliativo ante la ausencia de leyes que regularan actividades políticas de parte del movimiento obrero, que el Ministro no dudó en calificar como “desviacionismo bandolero".35 De acuerdo al testimonio del Ministerio, el peligro comunista resultaba la principal motivación del incremento de la violencia obrera entre los años 1932-1934, haciendo presentes nuevos elementos hasta ese momento no empleados por quienes ejercían este tipo de atentados contra el orden social y político. La novedad más relevante, de acuerdo a Melo, era el uso de "ayuda jurídica": la asistencia de abogados, algunos miembros del SRI, a detenidos políticos, acusados también de complicidad con esta "delincuencia social" por asesorar y desarrollar estrategias defensivas. Distintos profesionales del derecho, en gran parte pertenecientes al Socorro Rojo, fueron hostigados por la propia policía a razón de su función. 36

La revisión de los ejemplos provistos nos permite asegurar la existencia de indicios que validan la voluntad política por parte de la gestión de Justo para criminalizar las "actividades comunistas". Aun así, ello no implicó la

${ }^{34}$ Memorandum SERC, 20 de marzo de 1933, Doc. 69, Caja 45, Archivo Agustín P. Justo, AGN, p. 3. Acerca del Congreso y del antimilitarismo o antiguerrerismo comunista, ver Hernández (2016, 294-313) y Stefanoni (2014).

${ }^{35}$ Mensaje contestando el pedido de informes acerca de las razones que determinaron la creación en la Policía de la "Sección especial de represión contra el comunismo", Archivo de la Honorable Cámara de Diputados de la Nación, legajo nro. 115, 8 de agosto de 1934 .

${ }^{36}$ Mensaje contestando el pedido de informes acerca de las razones ..., folios 80-82. 
sanción de normativas que limitaran o proscribieran a nivel nacional al comunismo. Por el contrario, los dos proyectos ley presentados en 1932 y 1936 por el senador conservador Matías Sánchez Sorondo no encontraron el eco buscados; el primero no recibió tratamiento, mientras que el segundo solo obtuvo media sanción por la Cámara de Senadores. En lo relativo a ese segundo proyecto, más allá que el mismo no logró convertirse en ley, no debemos desdeñar el contexto y el debate que lo acompañó. Por un lado, entre sus motivaciones directas encontramos un conjunto de sucesos locales y externos que, combinados entre sí, validaban los temores del conjunto de conservadores, nacionalistas y católicos que apoyaron la propuesta de Sánchez Sorondo (Seveso 2007). Las repercusiones de la huelga general de enero, las tensiones dentro de conservadores y la extrema derecha por el posible desarrollo de la estrategia de Frente Popular en Argentina, tuvieron como marco al estallido de la Guerra Civil en España y el impacto del levantamiento de Luis Carlos Prestes a fines de 1935 en Brasil, caracterizado como una "intentona comunista" por la extrema derecha brasilera, las FFAA de ese país y el gobierno de Getulio Vargas (Patto Sá Motta 2019, 248-290).

Durante el debate en el Senado, Sorondo y otros partidarios del proyecto tomaron como antecedentes a los informes de la SERC para dar cuenta de la "realidad" de la amenaza comunista en el país (López Cantera 2014a). Ello también significó el repaso por las estrategias de inserción en el mundo sindical por el PC, sus líneas políticas y una nómina de organizaciones, algunas de ellas ligadas efectivamente al mencionado partido; otras asociadas erróneamente por compartir banderas como la del antifascismo o el reformismo universitario (caso de la Federación Universitaria Argentina). Corresponde preguntarnos en esta instancia de este trabajo cuán necesaria resultaba una ley de alcance nacional para ejercer un control sobre aquellas actividades políticas que eran calificadas como comunistas. Un aspecto que nos ayuda a evaluar esta necesidad son las sanciones, entre 1935 y 1937, de diversos decretos de proscripción sen las provincias de Salta, Mendoza, San Juan, San Luis, Corrientes, Catamarca, más el caso de la provincia de Buenos Aires bajo la gobernación de Manuel Fresco quien combinó estas medidas represivas con una política selectiva de negociación sindical desde 
su Departamento Provincial del Trabajo. ${ }^{37}$ En esa misma línea debemos considerar el despliegue policial en los Territorios Nacionales (TTNN), que permitió proyectar al entramado represivo a escala federal, junto con la labor de la SOS (denominada en algunos casos como Sección de Orden Social y Político) en las distintas policías locales, tal como ejemplifica la represión a trabajadores hacheros en el Territorio Nacional de La Pampa a comienzos de la década de 1940 (Gómez y Salvarredi 2018), la situación de colonos y trabajadores agrícolas en el T. N. del Chaco entre fines de los años treinta y principios de la siguiente década, y el caso de la detención del militante comunista Marcos Kanner en Misiones en 1942. ${ }^{38}$

Otra cuestión relevante es, finalmente, el mencionado pasaje de la dinámica preventiva a la ofensiva. En 1937 la conflictividad en distintas ramas productivas desencadenó diversas jornadas de protestas y reclamos, dentro de los cuales las tensiones al interior del rubro de la construcción volvieron a destacar. El Comité de Huelga de la Federación Obrera Nacional de la Construcción, creada en 1936, inició en agosto de ese año las negociaciones necesarias para la resolución del conflicto, contemplando la convocatoria a una huelga para el mes de septiembre. ${ }^{39}$ Sin embargo, la misma no pudo realizarse ya que todos los integrantes de ese comité fueron detenidos por la SERC, en paralelo a que el Ministro del Interior, Manuel Alvarado, solicitó la aplicación de la Ley 4144, lo que detonó campañas en

37 “A S. E. Ministro del Interior, del Jefe de Policía Gral. Div. (R.A.) J. E. Vacarezza”, en Memoria correspondiente al año 1936, 1 ero. de marzo de 1937, pp. 22-23; "Salta. Dio un decreto sobre represión al comunismo el Ejecutivo provincial", en La Nación, nro. 23443, año LXVII, 04/11/1936, p. 7. "Límites de acción contra el comunismo", en La Nación, nro. 23441, año LXVII, 02/11/1936, p. 6. Respecto a la represión anticomunista en la provincia de Buenos Aires, tanto sus orígenes como su posterior desarrollo en torno a la Dirección de Inteligencia de la Policía de la Provincia de Buenos Aires, puede consultarse la tesis doctoral de María Eugenia Marengo Hecker (2018).

${ }^{38}$ Ministerio de Guerra, A S. E. el Sr. Ministro del Interior Doctor Miguel Culaciati. Secreto ...1; Ministerio del Interior, Gobernación de Misiones. Detención y remisión a la Capital Federal del sujeto Marcos Kanner... .

${ }^{39}$ La creación tuvo lugar luego de las negociaciones resultantes de los conflictos del verano de 1936. La FONC fue ejemplo de la línea gremial impulsada por el PC que fomentó la formación de sindicatos únicos por rama, la participación de base a partir de la difusión de comités de empresa, y una política de diálogo con el DNT (Camarero 2012). 
contra de esta resolución por parte de la CGT, el PS y el PC, como así voces favorables por parte de la derecha nacionalista (López Cantera 2018). La deportación de los miembros del comité a fines del mes de octubre, entre los cuales figuraba el mencionado Fioravantti, reveló un cariz ofensivo por parte del entramado represivo que hasta ese momento no se había revelado tan nítidamente. ${ }^{40} \mathrm{El}$ temor a un conflicto de dimensiones como las de enero de 1936, la posibilidad de otra huelga general, habría abonado esta dinámica; no obstante, el carácter disciplinador que tuvo la aplicación de la Ley de Residencia en esta oportunidad no debe entenderse únicamente como desprendido de las repercusiones del verano del '36, sino como resultado de la maduración de las propuestas coercitivas ensayadas hasta ese momento.

En este punto conviene incorporar otros elementos presentes en la configuración de este entramado. Entre fines de la década de 1930 y las vísperas del golpe de Estado de 1943, las discusiones sobre la regulación del derecho de reunión y la actuación de diversas asociaciones nos permiten comprender el empleo de otros decretos gestados en el seno del Poder Ejecutivo, condicionados por la coyuntura internacional que marcó la guerra en Europa. Este control desplegado sobre acciones en solidaridad con los bandos europeos - donde se incluyen los mecanismos de control sobre la propaganda filonazi - encuentra su antecedente en las restricciones a la militancia antifascista durante el primer lustro de los años treinta, más las limitaciones a eventos en el marco de la guerra civil española, denunciados entre otros por la propia embajada del gobierno del Frente Popular. ${ }^{41} \mathrm{Si}$ contemplamos los análisis de otros actores de la época, como la extrema derecha nacionalista y el diverso mundo católico, más las conclusiones de la Policía de la Capital en relación al frentepopulismo que analizamos en el anterior apartado, el antifascismo habría sido comprendido como uno de los

${ }^{40}$ División de Investigaciones, SOS, 21 de septiembre de 1937, folios 1 a 22, Caja 149, AGN Intermedio, Reservados confidenciales.

41 Embajada de España, "Al Sr. Ministro", Buenos Aires, 7 de mayo de 1937, en División Política. Ministerio de Relaciones Exteriores y de Culto, 1937, Caja 11, legajo 40, Archivo Guerra Civil Española - Archivo Histórico de la Cancillería Argentina (AGCE-AHCA); "Denuncias formuladas por la embajada de España", en División Política. Ministerio de Relaciones Exteriores y de Culto, 20/04/1937, 26/04/1937, 11/08/1938, 29/07/1938, 16/08/1938, Caja 11, legajo 40, AGCE-AHCA. 
tanto "disfraces" del comunismo, una estrategia de camouflage que permitía expandir su influencia sobre otras indentidades partidarias y/o políticas. La confluencia entre estas lecturas nos permite comprender que las modificaciones a los edictos sobre asociaciones y reuniones públicas estarían lejos de ser inocuas respecto a organizaciones y eventos vinculados a la solidaridad con refugiados del régimen franquista, o con la lucha contra el avance del nazismo y el fascismo.

Fue en este marco en que otras decisiones estatales colaboraron en completar el total del entramado analizado. Al empleo de contravenciones, regulaciones sobre el espacio público, leyes como la de Residencia, debemos incorporar un comportamiento recurrente en las autoridades de la SERC. Diversas denuncias señalaron las dificultades de abogados y familiares para asentar habeas corpus en dependencias policiales frente al desconocimiento del paradero de militantes detenidos. Un ejemplo ilustrativo ocurrió en octubre de 1939 con la detención de militantes del PC, en sus domicilios particulares y sin orden judicial, que fueron conducidos a la comisaría nro. 8 de la calle Urquiza 566. Uno de ellos, Abraham Pergament, como castigo a su mala conducta fue trasladado a la comisaría de la localidad de Avellaneda; su familia no pudo exigir el recurso de habeas corpus en esa dirección dado que los agentes responsables de dicha dependencia no habían ingresado los datos de su persona. ${ }^{42}$ El recurso de amparo quedó sin efecto. No obstante, esa misma situación volvió a reiterarse en marzo de 1941 cuando ocurrió la detención de los dirigentes del SUOC, quienes fueron trasladados de la Comisaría $8^{\circ}$ al Departamento Central de Policía y viceversa, empleando la misma lógica del caso Pergament.

La evidencia de este tipo de prácticas coincidió con los informes del Ministerio del Interior recibidos por Cámara de Diputados acerca de las autorizaciones a reuniones públicas, el debate sobre el Estado de Sitio y el rol de la SERC. Aquí nos interesa señalar las hipótesis con la que el Poder Ejecutivo apañó el accionar de dicha dependencia y del conjunto de medidas

\footnotetext{
42 "Protestan por el malón policial” y "Secuestro de libretas de enrolamiento, torturas y ‘picana' eléctrica en la Sección Especial”, en Orientación, año III, 05/10/1939, p. 1 y pp. 5-6; "Concreta la Liga por los Derechos del Hombre por los abusos y atropellos de la Sección Especial”, en Orientación, año III, 12/10/1939, p. 6.
} 
que conformaron el mencionado entramado. La posición del ministro Culaciati en relación a las disposiciones y el incremento de hechos represivos fue explicada en un primer informe como resultado del "recrudecimiento de las actividades comunistas" en los últimos años, justificando la detención de dirigentes obreros a los que el gobierno consideraba "fermentos peligrosos de disolución social". ${ }^{43}$ Esto volvió a ser ratificado en la segunda interpelación de 1942 con una particularidad: Culaciati presentó como antecedente un fallo de la Corte Suprema de Justicia de la Nación sobre un caso de allanamiento y detención ocurrido en 1941 a un domicilio en el que supuestamente funcionaba una biblioteca del PC.

En el fallo Amador Spagnol, María Elena Álvarez de Shuster y Otros, el tribunal supremo determinó que la reunión que se estaba llevando a cabo en la dirección allanada revestía carácter ilícito e ilegal, dado por sus contenidos a los que consideraba en directa oposición al orden constitucional imperante. ${ }^{44}$ La justificación del dictamen se apoyaba en los siguientes antecedentes: el desafuero de Del Valle Iberlucea, la media sanción del proyecto de Sánchez Sorondo de 1936, y que la reunión prohibida respondía a intereses de un partido político contrario a las ideas democrático-liberales y funcional a una potencia extranjera. En segundo lugar, por esta resolución, la Corte ratificaba la facultad de la Policía de la Capital (que en este caso había actuado por medio de la SERC) para disolver actividades de esas características.

Resta incluir que, por último, el ministro Culaciati recurrió a acuerdos o alianzas internacionales que la Argentina había firmado en estos años para validar las políticas de excepción impartidas a partir de su tesis sobre la amenaza comunista. Un ejemplo lo constituyó la Conferencia de Río de Janeiro de enero de 1942, en la que se reafirmó la voluntad de las naciones

\footnotetext{
${ }^{43}$ Moción del diputado Manubens Calvet, para entregar a los señores diputados una copia de los informes del ministro del Interior, relacionada con la detención de dirigentes políticos y obreros, y de fijar mañana para tratar, como primer asunto, la interpelación sobre esta cuestión. Es aprobada. $80^{\circ}$ reunión $24^{\circ}$ sesión extraordinaria, 12 de marzo de 1941, HCDN, p. 530-536.

44 “Amador Spagnol, María Elena Álvarez de Shuster y Otros", Buenos Aires, 10 de diciembre de 1941, en Fallos de la Corte Suprema de Justicia de la Nación, Tomo 191, 1941, pp. 388-400.
} 
firmantes de impedir por medio de toda herramienta legislativa acciones o propaganda afines a poner en peligro a las instituciones democráticas. ${ }^{45} \mathrm{De}$ esta manera, el Poder Ejecutivo desde el Ministerio del Interior señalaba al comunismo ya no como un peligro para el "orden social/político" sino para el orden democrático. En esa misma línea, retomó las acusaciones contra asociaciones políticas vinculadas a campañas de solidaridad, que caracterizaron a las mismas como "disfraces del comunismo", para lo cual hizo mención a un documento perteneciente al Comité de Actividades Antinortemaricanas de EEUU sobre las llamadas "organizaciones de frente": asociaciones gestadas por simpatizantes del PC norteamericano que utilizaban convocatorias democráticas para obtener adeptos. ${ }^{46}$

El total de los documentos y testimonios revisados hasta este punto nos ayuda a enmarcar a las operaciones policiales analizadas en el primer apartado, dentro de una toma de posición por parte de los gobiernos que dieron forma a dinámicas represivas que se incorporaron a la estructura estatal. Aún contemplando estas consideraciones, resta una última reflexión sobre el significado del proceso que hemos reconstruido, lo que nos compromete a sistematizar los diagnósticos que hemos puesto en diálogo con la dimensión represiva del anticomunismo.

${ }^{45}$ La Conferencia de Río de Janeiro celebrada entre el 15 y el 28 de enero de 1942 (conocida como la Tercer Reunión de Consulta de Cancilleres de países americanos) ratificó las posiciones tomadas en la 8va. Conferencia Panamericana en Lima (1938) y la Segunda Reunión de Consulta de Cancilleres de países americanos en La Habana (1940), que reglamentaron el sistema de consultas entre los Estados americanos y neutralidad frente a asuntos externos.

${ }^{46}$ El informe citado era una investigación realizada entre 1939 y 1940 por el diputado por Alabama Joe Starnes (era representante demócrata y defensor de las leyes de segregación existentes en los estados sureños) por el que se denunciaban las organizaciones satélites del comunismo, la mayoría de ellas vinculadas a la lucha antifascista, el movimiento pro refugiados españoles y las entidades contra el racismo y defensa de los derechos de los afroamericanos. Se considera la interpelación al señor ministro del Interior..., pp. 178-179. 


\section{Conclusiones}

Si bien no es propósito de este trabajo arrojar una mirada de largo plazo, no podemos dejar de concebir a las transformaciones descriptas hasta aquí como parte de un proceso de observación, calificación y clasificación que encuentra sus raíces con el nacimiento y profesionalización de las fuerzas de seguridad, puntualmente la policía. Así como la represión ejercida contra el anarquismo desde comienzos de siglo colaboró en la estructuración de herramientas de disciplinamiento, lo que nos indica la presencia de continuidades, es necesario también señalar la existencia de una ruptura en torno a las modalidades de control que el mentado enemigo comunista le impuso al Estado argentino en los años treinta.

Este punto de inflexión no fue generado por la propia dinámica de desarrollo de las instituciones estatales, sino por la intencionalidad política que demostraron los diversos gobiernos ante la emergencia de lo que consideraron un peligro para el orden político como para aquellas ideas y valores que lo sustentaran; dicha problemática fue necesaria de ser explorada para determinar su novedad, es decir, conocer sus características y diferenciarla de otros actores que el Estado ya había calificado como ominosos. La Policía de la Capital, por medio de la SERC, pudo dar cuenta de la complejidad que revestía el nuevo sujeto a disciplinar: una organización partidaria, fuerte presencia en el mundo sindical, entidades satélites (y vinculadas a distintas esferas de la sociedad civil), más el apoyo de una nación extranjera, dieron cuerpo, voz y rostro, a la explicación de las problemáticas sociales y políticas que eran objeto de contención. Y en diálogo permanente con esto último se encontró la elaboración y el complemento de estrategias coercitivas; nuevos elementos, como la denunciada "ayuda jurídica", que no se habían encontrado presentes en el caso de la represión al anarquismo de comienzos de sigo, incidieron en la puesta en práctica de modalidades como la analizada "desviación" de habeas corpus, lo que suma a la hora de pensar en el giro que constituyeron estos años.

A pesar de estas particularidades, sería limitado entender a la "cuestión comunista" que el Estado fue construyendo en base a la irrupción del comunismo en tanto partido. La vigilancia, secuestro de materiales y detenciones llevadas a cabo por la SERC - sin descuidar la continua 
colaboración con la SOS y la SOP en la Capital como en el plano federal arrojan resultados que trascendieron la dimensión partidaria. La operación de clasificación realizada por las dependencias de la policía concluye en la peligrosidad de prácticas e ideas y valores políticos, a los que concibieron como promovidos por el comunismo y por lo tanto sus sinónimos, y que podían encontrarse en otras identidades políticas, posibles de ser calificadas como "comunizantes" o desviaciones resultantes de la presencia del temido fenómeno. Banderas como la solidaridad de clase o la solidaridad internacional (como el activismo antifascista), métodos de lucha como la huelga general, la prolongación de conflictos, el empleo de la violencia, fueron componentes homologados al comunismo que podían presentarse en otras militancias; dentro de estos cuestionamientos, no debe marginarse el señalamiento en diversas fuentes a la lucha de clases y a la igualdad de clases como pilares ideológicos que demuestran, en primer lugar, su carácter destructivo y, en segundo, su ajenidad a un orden concebido como natural.

Lo complejo de este nuevo actor y la coyuntura política que se le presentó a la Concordancia en 1932, abonaron la necesidad de una nueva dependencia al interior de la División de Investigaciones. La SERC se enriqueció de la experiencia adquirida con el trabajo de la SOP como de la SOS, pero es de esta última de quien resulta heredera: tanto Orden Social como la Sección Especial no abordaron objetivos punibles que puedan circunscribirse a una esfera estrictamente política. El comunismo fue entendido como un problema social, su alcance excedía a una organización partidaria. Los prontuarios derivados de la SOS que conformaron los primeros pasos de la novel sección nos permiten, además, reafirmar esta conclusión, aunque no debe desdeñarse el carácter del objeto observado para comprender las continuidades y rupturas que presentan ambas dependencias entre sí.

Estos aspectos nos conducen a un segundo punto. El estudio sobre las prácticas e ideas del peligro comunista resultó en la impugnación a las mismas, revelando y justificando el criterio aceptado por el Estado respecto a la militancia política y al activismo del movimiento obrero. El total del accionar policial - que debe incluir una mirada federal y la articulación entre policías provinciales con la de la Capital - permitió que el aparato estatal desarrolle un diagnóstico sobre qué elementos podían ser aceptados, y por lo tanto revestir legalidad, en lo que refiere a organizaciones partidarias, 
sindicales u otras de tipo político o social. La evaluación y conclusión que esto encerró, nos sugieren un pasaje desde una dimensión preventiva - en la que el abyecto actor aún era explorado - al desarrollo de modalidades de disciplinamiento que expresan un carácter ofensivo. Entendemos que la ausencia de una regulación proscriptiva, como los proyectos de Sánchez Sorondo, es resultado de ello. Esto significa, por un lado, entender que el conjunto de herramientas que comprendió el llamado entramado represivo, no hacía necesario una prohibición de alcance nacional. Pero, por otra parte, una ley que proscribiera al PC hubiera sido limitada en su alcance; el entramado analizado no comprendió exclusivamente a los militantes del comunismo argentino, sino que colaboró en extender la represión más allá, hacia la configuración de un tipo de activista entendido como un peligro para el orden social y político. En suma, le permitió al Estado argentino poner bases propias a la idea del enemigo interno.

La comprensión de esta última figura excede los límites de este trabajo. No obstante, las posiciones marcadas por el Poder Ejecutivo a través de los diversos informes del Ministerio del Interior, colaboran en dimensionar el peso del comunismo como problema político en los años abarcados. El último informe presentado por el ministro Culaciati en la segunda interpelación analizada, como el fallo de la Corte Suprema de 1941, demuestran que la denuncia contra la "amenaza roja" no era resultante de interpretaciones recientes en el marco de la contienda mundial, sino que era producto de un proceso de comprensión y descalificación de la misma, tal como demostró el repaso por los diversos antecedentes mencionados. Esta experiencia y estas herramientas generadas en la coyuntura de 1930-1943 terminaron por ser integrales al Estado. Resta preguntarnos por la manera en que ello acompañaría al despliegue de futuras medidas de disciplinamiento. Creemos que las preguntas que guíen a esas investigaciones necesitaran revisitar las hipótesis elaboradas sobre las décadas de la primera mitad del siglo, ciclo dentro del cual el período analizado aquí constituyó un punto de inflexión. 


\section{Referencias}

Armus, Diego. 1990. Mundo urbano y cultura popular. Buenos Aires: Sudamericana.

Asquini, Sabrina, y Walter L. Koppmann. 2020. "Espías, rusos y maximalistas en el verano de 1919. La Semana Trágica revisitada desde las fuentes diplomáticas y periodísticas”. Estudios 44: 165-183.

Barry, Viviana. 2019. "Usos policiales para la represión política en las primeras décadas del siglo XX”. Programa Interuniversitario de Historia Politica. Foros de Historia Política. www.historiapolitica.com Barry, Viviana. 2015. "Los pasos para la modernización policial. Reclutamiento e instrucción en la policía de la ciudad de Buenos Aires, 1880-1910". Saberes del crimen: delito, policía, prisión, 1870-1940, Polhis (en línea). http:/historiapolitica.com/dossiers/saberes-delcrimen/ (acceso marzo 2018).

Benclowicz, José. 2019. “'Un Estado dentro del Estado que ha creado un nuevo Código Penal': La Sección Especial de la Policía y la criminalización del comunismo hacia la década de 1930 en Argentina". Latin American Research Review 54 (3): 623-636. DOI: http://doi.org/10.25222/larr.165

Benclowicz, José. 2016. "Un movimiento de desocupados para la revolución. El Partido Comunista y la organización de los trabajadores desocupados hacia la década de 1930 en Argentina". Revista de Historia Latinoamericana y Argentina 2.

Bilsky, Edgardo. 1984. La Semana Trágica. Buenos Aires: CEAL.

Bisso, Andrés. 2005. Acción Argentina. Un antifascismo nacional en tiempos de Guerra Mundial. Prometeo: Buenos Aires.

Caimari, Lila. 2001. Apenas un delincuente. Crimen, castigo y cultura en la Argentina, 1880-1955. Buenos Aires: Siglo XXI.

- 2012. Mientras la ciudad duerme. Pistoleros, policías y periodistas en Buenos Aires, 1920-1945. Buenos Aires: Siglo XXI.

Camarero, Hernán. 2007. A la conquista de la clase obrera. Los comunistas y el mundo del trabajo en la Argentina, 1920-1935. Buenos Aires: Siglo XXI. 
2012. "Alcances del sindicalismo único por rama antes del peronismo: la experiencia de la Federación Obrera Nacional de la Construcción (FONC), 1936-1943". Estudios del Trabajo 43/44. - 2017. Tiempos Rojos. El impacto de la Revolución Rusa en Argentina. Buenos Aires: Sudamericana.

Campione, Daniel. 2018. La Guerra Civil española, Argentina y los argentinos. Buenos Aires: Luxemburg.

Casals Araya, Marcelo. 2016. La creación de la amenaza roja. Del surgimiento del anticomunismo en Chile a la «campaña del terror» de 1964. Santiago de Chile: LOM ediciones.

Díaz, Hernán (comp.). 2019. Espionaje y revolución en el Río de la Plata. Los archivos de una red diplomática de persecución al maximalismo (1918-1919). Buenos Aires: Imago Mundi.

Ceruso, D. 2015. La izquierda en la fábrica. La militancia obrera industrial en el lugar del trabajo, 1916-1943. Buenos Aires: Imago Mundi.

Franco, Marina. 2019. "El estado de excepción a comienzos del siglo XX: de la cuestión obrera a la cuestión nacional”. Avances del Cesor 20: 2951 .

Friedmann, German. 2010. Alemanes antinazis en la Argentina. Buenos Aires, Siglo XXI.

Galeano, Diego. 2009. "Las conferencias Sudamericanas de policías y la problemática de los "delincuentes viajeros", 1905-1920". En La policía en perspectiva histórica. Argentina y Brasil (del siglo XIX a la actualidad), organizado por Ernesto Bohoslavsky, Lila Caimari y Cristiana Schettini. Buenos Aires.

Galeano, Diego y Albornoz, Martín. 2016. "El momento Beastly: la Policía de Buenos Aires y la expulsión de extranjeros (1896-1904)”. Astrolabio 17.

- 2017. "Anarquistas y policías en el atlántico sudamericano: una red transnacional, 1890-1910”. Boletín del Instituto de Historia Argentina y Americana "Dr. Emilio Ravignani" 47: 101-134.

Gómez, Magalí y Federico Salvarredi. 2018. "Criminalizar al malón rojo. Sobre los archivos de la represión del Departamento de Investigaciones del Territorio Nacional de La Pampa (1943)". Cuadernos de Marte 15: 105-135. 
https://publicaciones.sociales.uba.ar/index.php/cuadernosdemarte/articl e/view/3399

González Aleman, Marianne. 2011. “¿Qué hacer con la calle? La definición del espacio público porteño y el edicto policial de 1932". Boletín del Instituto de Historia Argentina y Americana "Dr. Emilio Ravignani” 34. Hernández, Juan Luis. 2016. La Guerra del Chaco. Conflictos sociales, oposición política y debates intelectuales. Tesis Doctoral, FFLyL-UBA. Horowitz, Joel. 2015. El radicalismo y el movimiento popular (1916-1930). Buenos Aires: Edhasa.

Iñigo Carrera, Nicolás. 2016. La otra estrategia. La voluntad revolucionaria (1930-1935), Buenos Aires: Imago Mundi.

Kalmanowiecki, Laura. 1997. Military Power and Policing in Argentina 1900-1955. New York: PhD, New School for Social Research.

- 2020. "Origins and applications of political policing in Argentina". Latin America Perpectives 27 (2).

Lobato, Mirta. 2001. La vida en las fábricas. Trabajo, protesta y política en una comunidad obrera. Berisso (1904-1970). Buenos Aires: Prometeo.

López, Ignacio. 2018. La república del fraude y su crisis. Política y poder en tiempos de Roberto Ortiz y Ramón S. Castillo: Argentina, 1938-1943. Rosario: Prohistoria, 2018.

López Cantera, Mercedes. 2014a. "Detrás del debate. La cuestión comunista y la criminalización en la Ley de Represión al comunismo de 1936". Revista Contenciosa 3.

2014b. "Criminalizar al rojo. La represión al movimiento obrero en los informes de 1934 sobre la Sección Especial". Revista Archivos de historia del movimiento obrero y la izquierda 4.

. 2015a. "La estrategia del comunismo argentino en la mirada del nacionalismo reaccionario durante la década de 1930". Revista Páginas $7(15)$

http://revistapaginas.unr.edu.ar/index.php/RevPaginas/issue/view/15.

. 2015b. "¡Contra los pasquines rojos! El anticomunismo argentino y el procesamiento a la prensa obrera en 1932". XV Jornadas de Interescuelas/ Departamentos de Historia, Facultad de Humanidades y Ciencias Sociales. Universidad Nacional de la Patagonia San Juan Don Bosco. 
2018. "La representación obrera en disputa. El anticomunismo argentino en los conflictos de 1936 y 1937”. Conflicto Social 19: 133159.

. 2019. "Orígenes y consolidación del anticomunismo argentino (1917-1943)". Tesis Doctoral. Facultad de Filosofía y Letras, UBA.

. 2020. "Construir un enemigo en tiempos de neutralidad: anticomunismo y disciplinamiento detrás de los debates por el derecho de reunión en Argentina (1938-1943)". Páginas (12) 28. http://dx.doi.org/10.35305/rp.v12i28.377

Lvovich, Daniel. 2020. "El Gran Miedo de 1919 a escala global: la Semana Trágica argentina y los archivos norteamericanos". Estudios 43.

Marengo Hecker, María Eugenia. 2018. "Los servicios de inteligencia de la Policía de la Provincia de Buenos Aires y la construcción del "sujeto comunista" (1955-1962)". Tesis Doctoral, Universidad Nacional de la Plata.

Martínez Chas, María Lida. 2009. "Liderazgo Social y Militancia Comunista en la Provincia de Misiones: Una aproximación a la vida política e intelectual de Marcos Kanner". Tesis de Maestría, Centro de Estudios Avanzados - UNC.

Matshushita, Hiroshi. (1983) 2014. Movimiento obrero argentino, 19301945. Sus proyecciones en los orígenes del peronismo. Buenos Aires: RyR Ediciones.

Mayer, Arno. 2000. The Furies. Violence and terror in the French and Russian revolutions, Princenton: Princenton University Press.

Newton, Ronald. 1995. El cuarto lado del triangulo. La "amenaza nazi" en la Argentinas (1931-1947). Buenos Aires: Sudamericana.

Patto Sá Motta, Rodrigo. 2019. En guardia contra el peligro rojo. El anticomunismo en Brasil (1917-1964). Los Polvorines: UNGS.

Piemonte, Augusto. 2013. Alcances y significaciones de la incidencia soviética en las prácticas políticas del Partido Comunista de la Argentina (1919-1943). Tesis Doctoral. Facultad de Filosofía y Letras, UBA.

2015. "Las prácticas políticas del Partido Comunista de la Argentina ante la guerra civil española y su relación con la Internacional Comunista”. Historia Contemporánea 52: 179-209. 
Pittaluga, Roberto. 2015. Soviets en Buenos Aires. La izquierda de la Argentina ante la revolución en Rusia. Buenos Aires: Prometeo.

Potash, Robert. 1981. El Ejército y la política en la Argentina. De Yrigoyen a Perón. Buenos Aires: Sudamericana.

Publitskaia, María. 2013. Los libros rusos editados en Argentina. Moscú: Staraya Basmannaya.

Rodriguez, Adolfo. 1978. Historia de la Policía Federal Argentina, 19161944. Buenos Aires: Editorial Policial.

Rodríguez Molas, Ricardo. 1985. Historia de la Tortura y el Orden Represivo en la Argentina. Buenos Aires: Eudeba.

Rouquié, Alan. 1978. Poder militar y sociedad política en la Argentina, tomo I. Buenos Airess: Emecé.

Rubinzal, Marieña. 2012. "El Nacionalismo frente a la cuestión social en la Argentina. Discursos, representaciones y prácticas de las derechas sobre el mundo del trabajo". La Plata: Tesis Doctoral, UNLP.

Salvatore, Ricardo. 2000. "Criminología positivista: reforma de prisiones y la cuestión social obrera en Argentina". En La cuestión social en Argentina 1870-1943, editado por Juan Suriano. Buenos Aires: La Colmena.

Seveso, César. 2007. "A new Law for a new Crime: Anticommunism in Argentina, 1930-1940”. Journal of Iberian and Latino American Studies 13.

Stefanoni, Pablo. 2014. "Guerra a la guerra: comunismo, antiimperialismo y reformismo universitario durante la contienda del Chaco". Bolivian Research Review/Revista Boliviana de Investigación 1.

Troncoso, Oscar. 1983. Fundadores del gremialismo obrero. Buenos Aires: CEAL.

Vigreux, Jean. 2016. Histoire du Front Populaire. L'échappée belle. Paris: Tallandier.

Zanatta, Loris. 1996. Del Estado Liberal a la Nación Católica. Iglesia y Estado en los orígenes del peronismo, 1930- 1943. Bernal: UnQui Ed. Zimmermann, Eduardo. 1995. Los Liberales reformistas. La cuestión Social en la Argentina, 1890-1916. Buenos Aires: Sudamericana. 